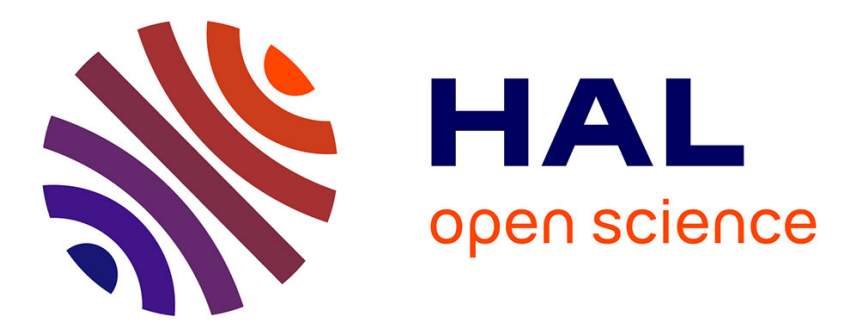

\title{
Electrochemical reactivity and stability of platinum nanoparticles in imidazolium-based ionic liquids
}

\author{
Miguel A. Montiel, Jose Solla-Gullón, Carlos M. Sanchez-Sanchez
}

\section{To cite this version:}

Miguel A. Montiel, Jose Solla-Gullón, Carlos M. Sanchez-Sanchez. Electrochemical reactivity and stability of platinum nanoparticles in imidazolium-based ionic liquids. Journal of Solid State Electrochemistry, 2016, 20 (4), pp.1043-1052. 10.1007/s10008-015-3014-5 . hal-01297973

\section{HAL Id: hal-01297973 \\ https://hal.sorbonne-universite.fr/hal-01297973}

Submitted on 8 Apr 2016

HAL is a multi-disciplinary open access archive for the deposit and dissemination of scientific research documents, whether they are published or not. The documents may come from teaching and research institutions in France or abroad, or from public or private research centers.
L'archive ouverte pluridisciplinaire HAL, est destinée au dépôt et à la diffusion de documents scientifiques de niveau recherche, publiés ou non, émanant des établissements d'enseignement et de recherche français ou étrangers, des laboratoires publics ou privés. 


\title{
Electrochemical Reactivity and Stability of Platinum
}

\section{Nanoparticles in Imidazolium-based Ionic Liquids}

\author{
Miguel A. Montiel ${ }^{a}$, Jose Solla-Gullón ${ }^{a}$, Carlos M. Sánchez-
}

Sánchez $z^{*, b, c}$

anstituto Universitario de Electroquímica, Universidad de Alicante, Ap.99, 03080 Alicante,

Spain

${ }^{b}$ Sorbonne Universités, UPMC Univ Paris 06, UMR 8235, Laboratoire Interfaces et Systèmes

Electrochimiques, F-75005, Paris, France

${ }^{c}$ CNRS, UMR 8235, LISE, F-75005, Paris, France.

*carlos.sanchez@upmc.fr

\section{ABSTRACT}

The electrocatalytic activity of synthesized quasi-spherical $\mathrm{Pt}$ nanoparticles (NPs) have been studied taking as a model the $\mathrm{CO}_{\text {ads }}$ electrooxidation reaction in two imidazolium-based ionic liquids such as 1butyl-3-methylimidazolium bis(trifluoromethylsulfonyl)imide $\left[\mathrm{C}_{4} \mathrm{mim}^{+}\right]\left[\mathrm{NTf}_{2}{ }^{-}\right]$and 1-butyl-3-methylimidazolium tetrafluoroborate $\left[\mathrm{C}_{4} \mathrm{mim}^{+}\right]\left[\mathrm{BF}_{4}\right]$. In particular, the effect of i) water content, ii) temperature and iii) nature of the room temperature ionic liquid (RTIL) on the electrocatalytic behavior of these Pt NPs have been systematically evaluated. The obtained results show how important are those parameters, since the $\mathrm{CO}_{a d s}$ oxidation peak potential exhibits a great sensitivity depending on the water content, temperature and nature of the RTIL used. Interestingly, the charge density associated with the $\mathrm{CO}_{\text {ads }}$ electrooxidation 
peak strongly depends on the nature of the ionic liquid, which reflects the complexity of this electrocatalytic reaction in this media. Moreover, Pt NPs electrocatalyst degradation in those RTILs, considered as loss of electrochemically active area, has been evaluated and shows high stability despite the extreme potentials afforded in RTILs.

Keywords: Platinum nanoparticles, ionic liquids, electrocatalysis, carbon monoxide.

\section{INTRODUCTION}

In the last decade, a myriad of contributions have been reported dealing with the use of room temperature ionic liquids (RTILs) as promising solvents for different electrochemical applications. RTILs are commonly defined as materials entirely composed of organic cations and organic or inorganic anions, which melt at or below $100{ }^{\circ} \mathrm{C}$. Particular physicochemical properties of RTILs including, low vapor pressure, high intrinsic conductivity and non-flammability $\left[{ }^{1},{ }^{2}, 3\right]$ confer them outstanding improvements in several and relevant electrochemical devices such as electrochemical sensors and biosensors, batteries and fuel cells. Then, those novel applications of RTILs in different electrochemical technologies are giving rise to a new generation of devices $\left[\begin{array}{c}4,6 \\ ,\end{array}\right]$, where safety concerns are not an issue. In particular, 1,3-dialkylimidazolium $\left[\mathrm{C}_{\mathrm{n}} \mathrm{mim}^{+}\right]$cations are one of the most common RTIL cations for electrochemical purposes, since they exhibit a high enough ionic conductivity. Moreover, it is well established in the literature that water content in RTILs may drastically affect their conductivity and electrochemical potential window. For 
this reason, we study here two different RTILs, in both the cation remains constant, 1-butyl-3-methylimidazolium $\left[\mathrm{C}_{4} \mathrm{mim}^{+}\right]$, but the anion differs, being the bis(trifluoromethylsulfonyl)imide $\left[\mathrm{NTf}_{2}{ }^{-}\right]$mainly hydrophobic and the tetrafluoroborate $\left[\mathrm{BF}_{4}\right]$ mainly hydrophilic. Some relevant properties of those two RTILs are shown in Table 1. For sake of comparison, Table 1 also contains physicochemical data for a $0.5 \mathrm{M} \mathrm{H}_{2} \mathrm{SO}_{4}$ aqueous solution. In particular, the most interesting point in Table 1 is the difference in viscosities, since the fair conductivity exhibited by both RTILs in comparison with the sulfuric aqueous solution is enough to carry out electrochemical reactions, but their high viscosity may represent an important drawback to solve in RTILs.

Table 1. Physicochemical properties of RTILs: conductivity $\left[^{7}\right]$, density [7] and water content $\left[{ }^{8}\right]$ at $298 \mathrm{~K}$ and viscosity [1] at $293 \mathrm{~K}$. Physicochemical properties of $0.5 \mathrm{M} \mathrm{H}_{2} \mathrm{SO}_{4}$ aqueous solution at $298 \mathrm{~K}\left[{ }^{9},{ }^{10}\right]$.

\begin{tabular}{|l|c|c|c|c|}
\hline & $\begin{array}{c}\text { Conductivity } \\
(\mathrm{mS} / \mathrm{cm})\end{array}$ & $\begin{array}{c}\text { Density } \\
\left(\mathrm{g} / \mathrm{cm}^{3}\right)\end{array}$ & $\begin{array}{c}\text { Viscosity } \\
(\mathrm{cP})\end{array}$ & $\begin{array}{c}\text { Maximum } \mathrm{H}_{2} \mathrm{O} \\
\text { content }(\mathrm{ppm})\end{array}$ \\
\hline$\left[\mathrm{C}_{4} \mathrm{mim}^{+}\right]\left[\mathrm{BF}_{4}{ }^{-}\right]$ & 3.5 & 1.21 & 154 & Miscible \\
\hline$\left[\mathrm{C}_{4} \mathrm{mim}^{+}\right]\left[\mathrm{NTf}_{2}{ }^{-}\right]$ & 3.9 & 1.43 & 52 & 5680 \\
\hline $0.5 \mathrm{M} \mathrm{H}_{2} \mathrm{SO}_{4}$ & 223.2 & 1.033 & 1.01 & $-\cdots$ \\
\hline
\end{tabular}

On the other hand, the use of nanoparticles (NPs) as electrode material have produced relevant improvements on the performance of different electrochemical energy devices such as batteries and fuel cells $\left[{ }^{11},{ }^{12},{ }^{13},{ }^{14},{ }^{15}\right]$. This is mainly due to their elevated surface to volume ratio, particularly important for scaling up highly expensive noble metal based catalysts. For this 
reason, studying electrocatalytic reactions at NPs concentrates a lot of attention for developing new energy sources. In this sense, noble metal nanoparticles, and particularly platinum nanoparticles (Pt NPs), have been extensively investigated as electrocatalysts for those types of devices $\left[{ }^{16},{ }^{17},{ }^{18},{ }^{19}\right]$. Nevertheless, only in the last few years, a combined use of metallic NPs and RTILs as a solvent-supporting electrolyte system has been proposed in the literature, but mainly in other type of applications different than electrocatalysis, such as biosensors, synthesis of nanoparticles $\left[{ }^{20}, 21,22,23\right]$, as well as for preparing composite electrodes in which the RTIL mainly acts as a binder $\left[{ }^{24}\right]$ or intercalator $\left.{ }^{25}\right]$. However, to the best of our knowledge, a detailed characterization of the Pt NP-RTIL interface from an electrocatalytic point of view has been scarcely reported. Furthermore, important effects such as temperature and water content on the resulting electrocatalytic properties of Pt NPs in RTILs remain almost unexplored. Consequently, we describe herein a general experimental methodology to study/analyze the electrochemical response of quasi-spherical Pt NPs in two different RTILs, $\left[\mathrm{C}_{4} \mathrm{mim}^{+}\right]\left[\mathrm{NTf}_{2}{ }^{-}\right]$and $\left[\mathrm{C}_{4} \mathrm{mim}^{+}\right]\left[\mathrm{BF}_{4}^{-}\right]$. In addition to this, we study the electrooxidation of carbon monoxide (CO) on Pt NPs in those RTILs by the CO stripping voltammetry as a model and technologically relevant electrocatalytic reaction. As recently reported by Hanc-Scherer et al. $\left[{ }^{26}\right]$, this electrocatalytic reaction exhibits a surface structure sensitive behavior at the $\mathrm{Pt}(h k l)-\mathrm{RTIL}$ interface in two short alkyl-chain imidazolium-based RTILs such as $\left[\mathrm{C}_{2} \min ^{+}\right]\left[\mathrm{BF}_{4}^{-}\right]$and $\left[\mathrm{C}_{2} \min ^{+}\right]\left[\mathrm{NTf}_{2}{ }^{-}\right]$. Interestingly, the charges associated with the $\mathrm{CO}$ electrooxidation process at the $\mathrm{Pt}(h k l)$ single-crystal electrodes reported there were not only much higher than expected, since the corresponding associated charge in aqueous media is 
approximately $300 \mu \mathrm{C} \mathrm{cm}^{-2}\left[{ }^{27}\right]$, but also sensitive to the nature of the RTIL anion. Ejigu et al. $\left[{ }^{28}\right]$ also studied the electrochemical oxidation of $\mathrm{CO}$ by stripping voltammetry at Pt polycrystalline electrodes varying the temperature in a different type of RTIL, a protic ionic liquid. They reported an evident shift in the $\mathrm{CO}$ oxidation stripping peak towards more negative potentials when increasing the temperature. This is a similar behavior to that observed in aqueous media, which was attributed to the formation of an adsorbed layer of $\mathrm{OH}_{\text {ads }}$ at more negative potential values when increasing the temperature $\left[{ }^{29}\right]$. $\mathrm{OH}$ radical adsorption represents the rate determining step for achieving complete oxidation of $\mathrm{CO}_{\text {ads }}$ to $\mathrm{CO}_{2}$ by following the reaction scheme 1 . More recently, Ejigu and Walsh $\left[^{30}\right]$ studied, for a series of protic ionic liquids, the important role during the electrooxidation of $\mathrm{CO}$ at $\mathrm{Pt}$ surfaces played by the specific adsorption of the cations and the anions forming the RTIL studied. In particular, they performed CO-displacement measurements to estimate the potential of zero total charge (pztc) and they reported the predominant adsorption of $\left[\mathrm{NTf}_{2}{ }^{-}\right]$on $\mathrm{Pt}$ even at relatively low potential values, which strongly affects the resulting electrocatalytic properties of Pt in this media. Finally, Yang et al. $\left[{ }^{31}\right]$ studied using infrared spectroscopy, the potential-induced structure at the Pt-RTIL interface and the dynamic ion variation on CO-covered $\mathrm{Pt}$ electrodes in $\left[\mathrm{Pip}_{14}{ }^{+}\right]\left[\mathrm{TNf}_{2}{ }^{-}\right]$. They reported a gradual conversion from bridge $\mathrm{CO}$ to linear $\mathrm{CO}$ as the electrode potential shifts towards positive values as a consequence of a strong electrostatic interaction of the adsorbed $\mathrm{CO}$ with the cation $\left[\mathrm{Pip}_{14}{ }^{+}\right]$. Such $\mathrm{CO}_{\mathrm{ads}}$ conversion had not been observed in previous contributions by the Baldelli's group using sum frequency generation spectroscopy measurements of CO-covered Pt electrodes in imidazolium-based 
RTILs $\left[{ }^{32}, 33,34\right]$. All these previous contributions studying the electrooxidation of $\mathrm{CO}$ in different RTILs pointed out the important role that the i) temperature, ii) water content and iii) nature of RTIL play on the subsequent electrocatalytic properties of $\mathrm{Pt}$ in those particular RTILs. Thus, owing to the necessary transition from bulk electrodes to NPs for scaling-up the catalysts involved in energy production electrochemical devices, we study for the first time in this paper some of those effects, but using unsupported Pt NPs instead of bulky Pt electrodes. Moreover, we evaluate the Pt NPs degradation in the studied RTILs.

$$
\mathrm{Pt}-\mathrm{CO}_{\mathrm{ads}}+\mathrm{Pt}-\mathrm{OH}_{\mathrm{ads}} \rightarrow 2 \mathrm{Pt}+\mathrm{CO}_{2}+\mathrm{H}^{+}+\mathrm{e}^{-}
$$

\section{EXPERIMENTAL}

\section{Chemicals}

All chemicals were reagent grade and were used without further purification. $\mathrm{H}_{2} \mathrm{SO}_{4}$ 95-97\% from Merck, acetone $\left(\mathrm{CH}_{3} \mathrm{COCH}_{3}\right)$ from Fisher Scientific, ferrocene $\left(\mathrm{Fe}\left(\mathrm{C}_{5} \mathrm{H}_{5}\right)_{2}\right) 98 \%, \mathrm{H}_{2} \mathrm{PtCl}_{6} \cdot 6 \mathrm{H}_{2} \mathrm{O}$, polyethylene glycol dodecyl ether $\left(\mathrm{BRIJ}{ }^{\circledR} 30\right)$ and hydrazine monohydrate $\left(\mathrm{N}_{2} \mathrm{H}_{4} \bullet \mathrm{H} 2 \mathrm{O}\right)$ 98\% from Sigma-Aldrich, n-heptane $99+\%$ from Across Organics and 1-butyl-3methylimidazolium bis(trifluoromethylsulfonyl)imide $\left[\mathrm{C}_{4} \mathrm{mim}^{+}\right]\left[\mathrm{NTf}_{2}{ }^{-}\right] 99 \%$ and 1butyl-3-methylimidazolium tetrafluoroborate $\left[\mathrm{C}_{4} \mathrm{mim}^{+}\right]\left[\mathrm{BF}_{4}{ }^{-}\right] 99 \%$ from lolitec. Karl Fisher titrations were performed for measuring the water content of both RTILs [8], being 50 or 480 ppm in $\left[\mathrm{C}_{4} \mathrm{mim}^{+}\right]\left[\mathrm{NTf}_{2}{ }^{-}\right]$and $600 \mathrm{ppm}$ in $\left[\mathrm{C}_{4} \mathrm{mim}^{+}\right]\left[\mathrm{BF}_{4}^{-}\right.$ ]. All solutions were prepared with high-purity Milli-Q water with resistivity $>18$ Megaohm cm at $25{ }^{\circ} \mathrm{C}$. Argon (99.995\% Alphagaz) and CO (99.995\% Alphagaz) gases were used in all experiments.

\section{Synthesis of platinum nanoparticles}


The experimental details for the synthesis and surface cleaning of the quasi-spherical Pt NPs studied here are extensively detailed in some previous contributions [16]. Very briefly, the Pt NPs were synthesized by reduction of $\mathrm{H}_{2} \mathrm{PtCl}_{6}$ with hydrazine by mixing equal volumes of two different water-in-oil (w/o) microemulsions composed by a mixture of water (3\%) / polyethylene glycol dodecyl ether $\left(\mathrm{BRIJ}^{\circledR} 30\right)(16.5 \%)$ / n-heptane $(80.5 \%)$ (the values in brackets represent the volume percentage of each compound). One of those microemulsions containing $0.1 \mathrm{M} \mathrm{H}_{2} \mathrm{PtCl}_{6}$ and the other one $2.5 \mathrm{M}$ hydrazine. After complete reduction, which takes place in a few minutes, acetone is added to the solution to cause phase separation. Then, the precipitate formed by the Pt NPs is repeatedly washed with acetone, acetone-water mixtures and water in order to eliminate surfactant molecules. Finally, clean Pt NPs are stored in ultrapure water as a suspension.

\section{Physical characterization by TEM}

The size and distribution of the synthesized Pt NPs were characterized using a Transmission Electron Microscopy (TEM, JEOL, JEM-2010 microscope working at $200 \mathrm{kV}$ ) and a High Resolution Transmission Electron Microscopy (HRTEM, JEOL 3010 microscope (LaB6, Cs=1.1 mm) operated at $300 \mathrm{kV}$ ). The samples for TEM analyses were prepared by placing a drop of the final water suspension of Pt NPs onto a Formvar-covered copper grid and evaporating it in air at room temperature. More than 100 particles from different parts of the grid were used to estimate the average particle size.

\section{Electrochemical measurements}

Three different electrochemical cells were sequentially used for each electrochemical experiment: i) Initial and final Pt NPs electrochemical 
characterization in $0.5 \mathrm{M} \mathrm{H}_{2} \mathrm{SO}_{4}$ aqueous solution, ii) $\mathrm{CO}$ adsorption on the $\mathrm{Pt}$ NPs surface under controlled potential in RTILs and iii) CO stripping voltammetry in RTILs. In all cases a one compartment electrochemical glass cell with a three-electrode configuration was employed for performing all cyclic voltammetry experiments. In all cases the working electrode was prepared by depositing a controlled volume (from 1 to $10 \mu \mathrm{L}$ ) of the sonicated aqueous suspension containing the synthesized Pt NPs $\left(0.0195 \mathrm{~cm}^{2} \mu \mathrm{L}^{-1}\right)$ on a glassy carbon (GC) disc (3 mm diameter, $0.071 \mathrm{~cm}^{2}$ geometrical area), which acts as inert current collector for the electrochemical response of the Pt NPs. Then, the water in the sample was allowed to be evaporated under an $\mathrm{Ar}$ atmosphere before placing the working electrode within the electrochemical cell. Before each new experiment, the GC disc current collector was mechanically polished with alumina $0.05 \mu \mathrm{m}$, sonicated and rinsed with ultra-pure water to make sure that all NPs from previous experiments were removed. The reversible hydrogen electrode (RHE) was used as a reference electrode connected to the cell through a Luggin capillary for all cyclic voltammetry experiments in aqueous media. In contrast, potential values in RTILs were referred versus a quasireference electrode (Pt wire). For this reason, and in order to compare those data, ferrocene was added at the end of each experiment to use the reversible one-electron oxidation of ferrocene as a reference standard compound, which is well-accepted as a convenient redox potential scale in RTILs $\left[{ }^{35}\right]$. Thus, all potentials reported here in RTILs have been transferred from Pt wire to the ferrocene/ferrocenium $\left(\mathrm{Fc} / \mathrm{Fc}^{+}\right)$potential scale. Being $\mathrm{E}\left(\mathrm{Fc} / \mathrm{Fc}^{+}\right)=0.105 \mathrm{~V}$ vs $\mathrm{Pt}$ wire in $\left[\mathrm{C}_{4} \mathrm{mim}^{+}\right]\left[\mathrm{BF}_{4}\right]$ and $\mathrm{E}\left(\mathrm{Fc} / \mathrm{Fc}^{+}\right)=0.140 \mathrm{~V}$ vs Pt wire in $\left[\mathrm{C}_{4} \mathrm{mim}^{+}\right]\left[\mathrm{NTf}_{2}{ }^{-}\right]$. A platinum wire ( $0.5 \mathrm{~mm}$ diameter) was used as a counter electrode in all cases. 
All electrochemical measurements were made using a VMP3 multichannel potentiostat from BioLogic.

i) Initial and final Pt NPs electrochemical characterization in deaerated $0.5 \mathrm{M}$ $\mathrm{H}_{2} \mathrm{SO}_{4}$ aqueous solution (volume $=50 \mathrm{~mL}$ ). This is done by cyclic voltammetry between the limits 0.05 and $0.8 \mathrm{~V}$ vs RHE, before and after performing the electrochemical characterization of Pt NPs in the RTILs, because it is necessary to warranty the surface cleanness and also determining the effective surface area of the Pt NPs. The active surface area of the Pt NPs was determined by quantifying the charge involved in the so-called hydrogen under potential deposition (UPD) region (between $0.06 \mathrm{~V}$ and $0.4 \mathrm{~V}$ vs $\mathrm{RHE}$ ) after the subtraction of the double layer contribution and assuming $210 \mu \mathrm{C} \mathrm{cm}^{-2}$ as the calibration charge density for the desorption of a complete monolayer of $\mathrm{H}$ atoms on a Pt electrode $\left[{ }^{36}\right]$.

ii) CO adsorption on Pt NPs surface for $20 \mathrm{~min}$ at controlled potential $(-1.2 \mathrm{~V}$ vs $\mathrm{Fc} / \mathrm{Fc}^{+}$) in a $\mathrm{CO}$ saturated (after $30 \mathrm{~min}$ of $\mathrm{CO}$ bubbling) RTIL solution (volume $=2.5 \mathrm{~mL}$ ). The Pt NPs placed on a GC disc, which acts as inert current collector, previously characterized in $0.5 \mathrm{M} \mathrm{H}_{2} \mathrm{SO}_{4}$ aqueous solution, were rinsed with acetone to remove the interfacial water and dried under an $\mathrm{Ar}$ stream before being introduced in contact with the RTIL. Prior to any experiment using RTILs, the electrochemical cell was dried in hot air and Ar gas was flowed into the empty cell in order to remove any trace of water.

iii) Thermostatic CO stripping voltammetry in RTIL solution (volume $=3.5 \mathrm{~mL}$ ). After completing the adsorption of $\mathrm{CO}$ on the Pt NPs placed on a GC disc, which acts as inert current collector, this electrode was transferred into a thermostatic jacketed glass cell coupled to a temperature controlled oil bath, 
where the electrode is introduced at open circuit potential (about $-0.7 \mathrm{~V}$ vs $\mathrm{Fc} / \mathrm{Fc}^{+}$) and where is cycled up to $1.65 \mathrm{~V}$ to electrochemically oxidize the adsorbed CO. In this cell, a vigorous Ar flow is continuously passed on top of the RTIL (not bubbled) to prevent changes in the water content of the RTIL. The effect of the temperature in the CO stripping voltammetry was evaluated by changing the temperature of the thermostatic oil bath. The water content was increased by exposing the particular RTIL studied to a water saturated Ar gas flow bubbling the RTIL for at least 30 min, which increases dramatically the water content in the RTIL.

\section{RESULTS}

Figure 1 shows representative TEM and HRTEM images of the synthesized Pt NPs. As it was already shown in previous contributions $\left[{ }^{37}, 38\right]$, these NPs present a quasi-spherical shape and an average diameter size of $4.5 \pm 0.8 \mathrm{~nm}$. It is worth noting that, as expected, the Pt NPs are agglomerated. However, these aggregates are clearly formed by individual NPs. This is due to the fact that the TEM samples are prepared from the final NPs water suspension, i.e. after the chemical removal of the surfactant employed in the synthesis and, consequently, those NPs tend to stay together, although they remain fully accessible for electrocatalytic purposes $[37,38]$. 

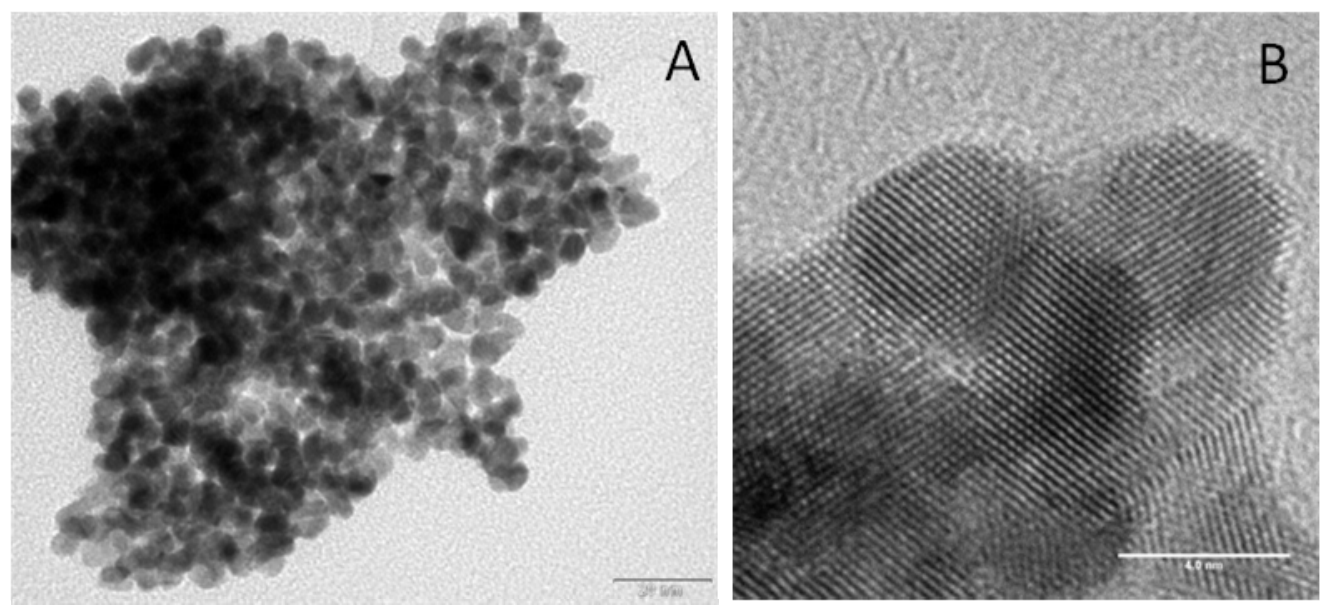

Figure 1. (A) TEM and (B) HRTEM of the synthesized Pt NPs.

Figure 2 shows the characteristic voltammogram of Pt NPs in $0.5 \mathrm{M}$ $\mathrm{H}_{2} \mathrm{SO}_{4}$ aqueous solution. This voltammetric profile is similar to that reported for polycrystalline Pt electrodes, but only shows the presence of two specific adsorption sites due to the presence of different crystallographic sites at the $\mathrm{Pt}$ NPs surface. One adsorption state at $0.12 \mathrm{~V}$ associated with (110) sites and another adsorption state at $0.27 \mathrm{~V}$ related to (100) step sites. In addition, these Pt NPs do not show contributions coming from large ordered terrace domains of (100) and (111) symmetry, which should be denoted by peak contributions at 0.35 and $0.5 \mathrm{~V}$, respectively. Furthermore, the comparison of those characteristic voltammograms before and after the interaction between the $\mathrm{Pt}$ NPs and the two different RTILs would allow to study their effect over Pt NPs and hence its stability in RTILs media. 


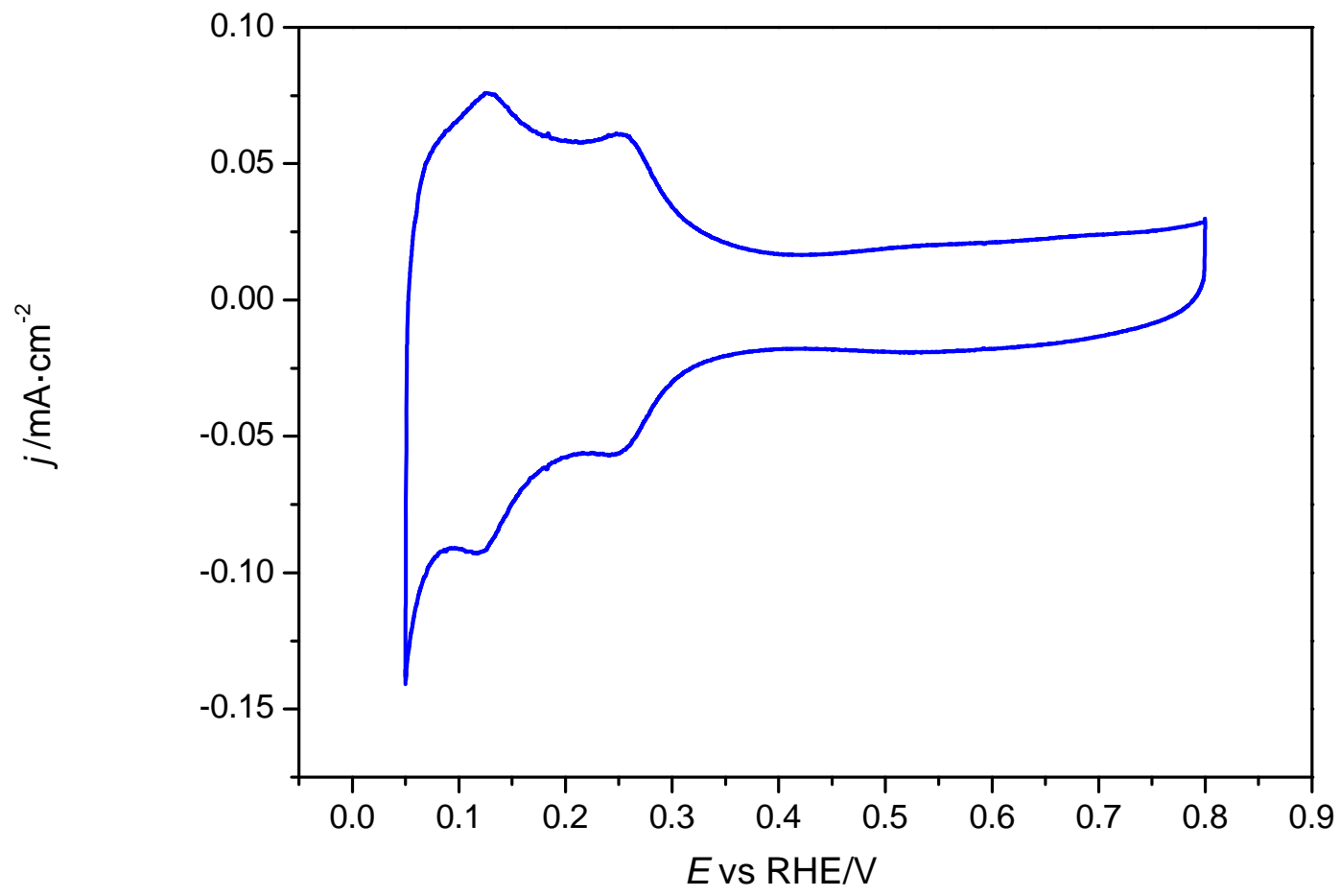

Figure 2. Voltammetric profile of Pt NPs in $0.5 \mathrm{M} \mathrm{H}_{2} \mathrm{SO}_{4}$ aqueous deaerated solution at $50 \mathrm{mV} \mathrm{s}^{-1}$.

Once Pt NPs are characterized in aqueous solution, we study the important effects played by water content, temperature and nature of RTIL on the electrocatalytic properties of Pt NPs using the electrooxidation of $\mathrm{CO}_{\text {ads }}$ as a model reaction. Firstly, the water content effect is evaluated by keeping constant the cell temperature at $298 \mathrm{~K}$ and only using $\left[\mathrm{C}_{4} \mathrm{mim}^{+}\right]\left[\mathrm{NTf}_{2}{ }^{-}\right]$, which is not totally miscible with water. Thus, figure 3 shows the stripping voltammetry of $\mathrm{CO}_{\mathrm{ads}}$ on Pt NPs in $\left[\mathrm{C}_{4} \mathrm{mim}^{+}\right]\left[\mathrm{NTf}_{2}{ }^{-}\right]$in the presence of different amounts of water. It is well-accepted that the amount of water dissolved in RTILs plays a critical role in most of their physical properties (viscosity, conductivity, density $\left.\left[{ }^{39}, 40\right]\right)$. Consequently, it is important to evaluate how the electrocatalytic properties of Pt NPs may be altered by the presence of water in RTILs. Figure 3 
shows two independent stripping voltammetries of $\mathrm{CO}_{\text {ads }}$ on Pt NPs, where the water content in each case varies from $50 \mathrm{ppm}$ to that resulting after water saturation of $\left[\mathrm{C}_{4} \mathrm{mim}^{+}\right]\left[\mathrm{NTf}_{2}{ }^{-}\right]$by bubbling water-saturated $\mathrm{Ar}$, which is $5680 \mathrm{ppm}$ [8]. The same type of study is not affordable using $\left[\mathrm{C}_{4} \mathrm{mim}^{+}\right]\left[\mathrm{BF}_{4}\right]$, since this RTIL is totally miscible with water.

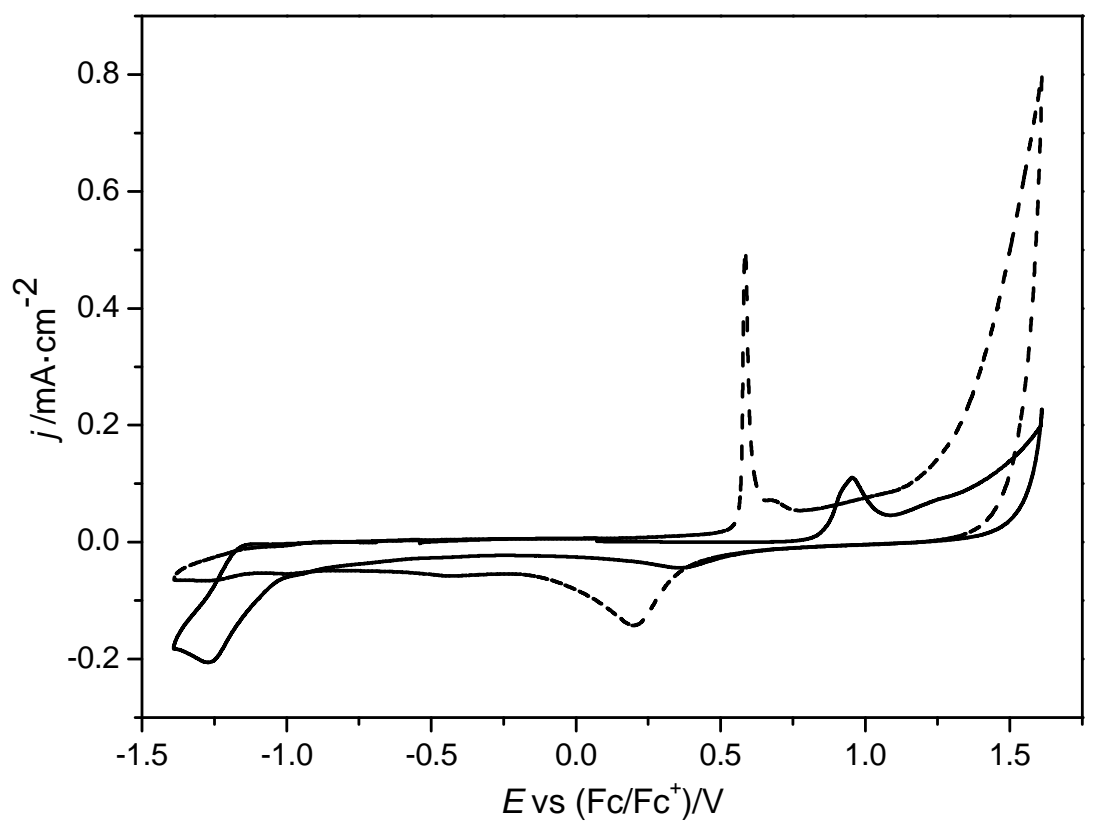

Figure 3. Stripping voltammetry of $\mathrm{CO}_{\text {ads }}$ on Pt NPs in argon saturated $\left[\mathrm{C}_{4} \mathrm{mim}^{+}\right]\left[\mathrm{NTf}_{2}{ }^{-}\right.$ ] containing 50 ppm $\mathrm{H}_{2} \mathrm{O}$ (black solid line) and 5680 ppm $\mathrm{H}_{2} \mathrm{O}$ (black dashed line) at $298 \mathrm{~K}$. Scan rate $20 \mathrm{mV} \mathrm{s}^{-1}$.

As can be observed, important differences in CO oxidation peak potential and shape are shown in figure 3. These differences can be mainly attributed to a higher availability of $\mathrm{H}_{2} \mathrm{O}$ to form $\mathrm{OH}$ adsorbed species at the Pt surface when the water content increases. This fact is also evident by comparing the positive potential region in both voltammograms, since the Pt surface oxidation appears at more negative potential values under water saturation conditions. This is 
accompanied by a remarkably increase of the current at higher potential than 1.2 V, which may be attributed to a higher contribution of the water oxidation reaction. This later feature is, in fact, direct consequence of the first one and is related to the subsequent reduction of the oxidised Pt surface, which takes place at a potential below $0.5 \mathrm{~V}$, and that is significantly higher in the case of water-saturated $\left[\mathrm{C}_{4} \mathrm{mim}^{+}\right]\left[\mathrm{NTf}_{2}{ }^{-}\right]$.

Consequently, as water content increases (figure 3, dashed line), the Pt$\mathrm{OH}_{\text {ads }}$ species are available at lower potentials, which not only activates the $\mathrm{CO}_{\text {ads }}$ electrooxidation, but also makes this oxidation faster as can be deduced from the sharp shape of the $\mathrm{CO}_{\text {ads }}$ oxidation peak. In contrast, if the $\mathrm{OH}$ source is limited (figure 3, solid line), the $\mathrm{CO}_{\text {ads }}$ electrooxidation takes place at higher potential and its corresponding peak is wider. However, and despite this different water content, the charge involved in the $\mathrm{CO}_{\text {ads }}$ electrooxidation reaction displayed in figure 3 is almost equal $\left(620 \mu \mathrm{C} \mathrm{cm}^{-2}\right)$ in both cases, as expected from a CO stripping experiment in which the CO coverage is restricted to a single monolayer. In order to perform a proper evaluation of the charge density strictly corresponding to the CO stripping peak, with the minimum contribution from concomitant oxidation of the RTIL anion or other secondary reactions, a similar approach to that used in aqueous solution and based on subtracting the subsequent voltammogram after $\mathrm{CO}_{\text {ads }}$ stripping is performed $\left[{ }^{41}\right]$. Figure 4 shows two consecutive voltammograms, where $\mathrm{CO}_{\mathrm{ads}}$ is only present in the first potential scan and then, the second potential scan accounts for all secondary concomitant reactions happening at the same potential. 

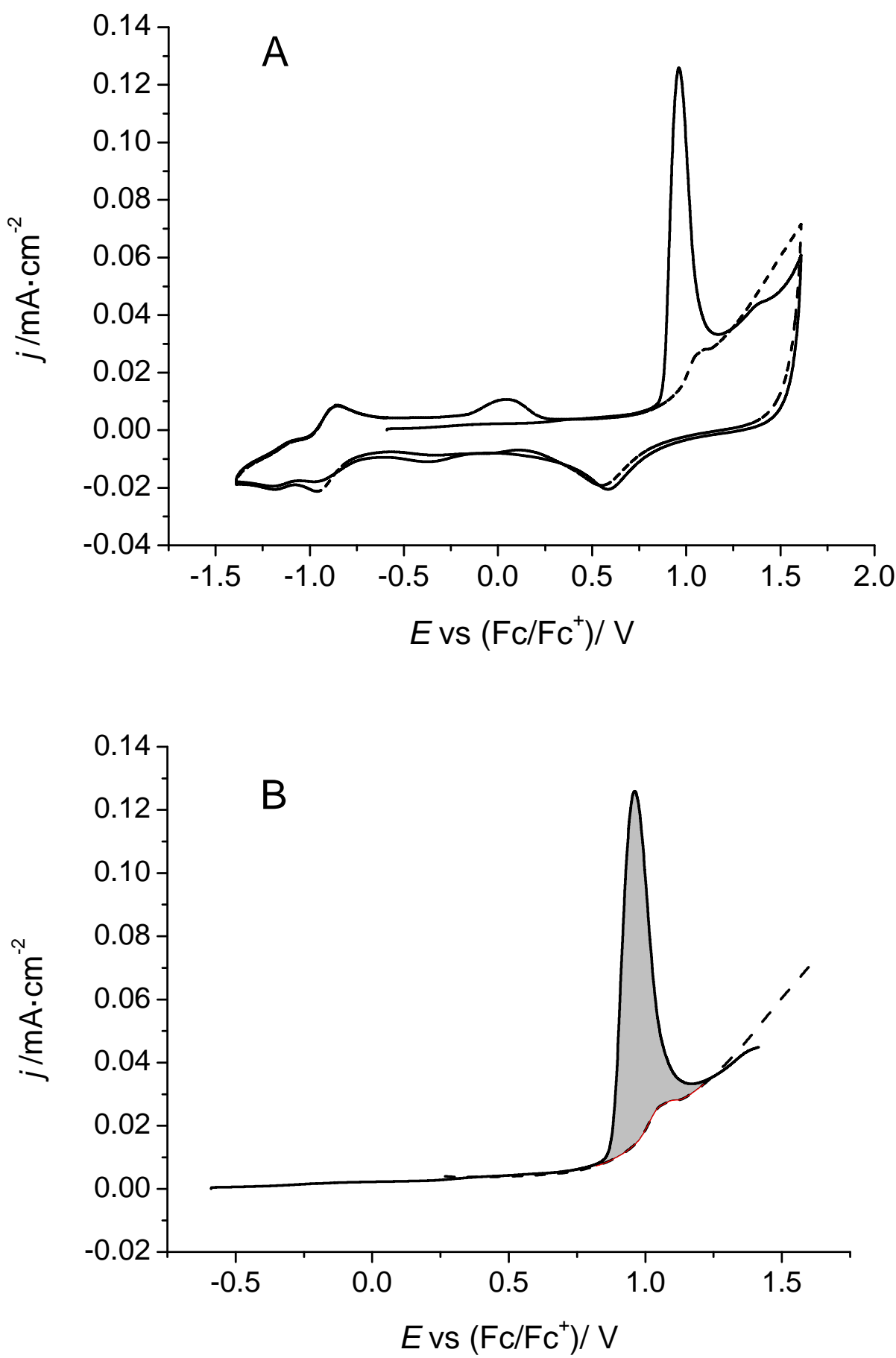

Figure 4. Two consecutive stripping voltammetries of $\mathrm{CO}_{\text {ads }}$ in argon saturated $\left[\mathrm{C}_{4} \mathrm{mim}^{+}\right]\left[\mathrm{NTf}_{2}{ }^{-}\right]$containing $480 \mathrm{ppm} \mathrm{H}_{2} \mathrm{O}$ at $298 \mathrm{~K}$. Scan rate $20 \mathrm{mV} \mathrm{s}^{-1}$. First potential cycle (black solid line) and second potential cycle (black dashed line) A) Full cyclic voltammograms and B) Linear voltammograms within the integration range of potential. 
The water content effect in RTILs does not only affect electrocatalytic reactions such as $\mathrm{CO}_{\text {ads }}$ electrooxidation, since this also significantly affects the extension of the potential electrochemical window, which is narrowed when water content increases [8]. In this regard, figure 5 shows the blank voltammetric profiles of the Pt NPs in $\left[\mathrm{C}_{4} \mathrm{mim}^{+}\right]\left[\mathrm{NTf}_{2}{ }^{-}\right]$with different water contents at $298 \mathrm{~K}$. In these voltammograms, the potential window was limited from -2.15 to $1.35 \mathrm{~V}$ vs $\mathrm{Fc} / \mathrm{Fc}^{+}$to minimize the water oxidation reaction and easily compare the shift observed in the onset potential for the hydrogen evolution reaction. In addition to the multiple waves attributed to the contributions of the different ions present in the $\left[\mathrm{C}_{4} \mathrm{mim}^{+}\right]\left[\mathrm{NTf}_{2}{ }^{-}\right]$, the most relevant feature in figure 5 is the clear shift towards less negative potentials of about $250 \mathrm{mV}$ on the onset for hydrogen evolution reaction in water-saturated $\left[\mathrm{C}_{4} \mathrm{mim}^{+}\right]\left[\mathrm{NTf}_{2}{ }^{-}\right]$. Moreover, a clear peak appears at $-1.2 \mathrm{~V}$, which is almost negligible in the water-saturated $\left[\mathrm{C}_{4} \mathrm{mim}^{+}\right]\left[\mathrm{NTf}_{2}{ }^{-}\right]$. It is feasible to believe that this peak may be due to a radical-radical reaction, which is only possible in $\left[\mathrm{C}_{4} \mathrm{mim}^{+}\right]\left[\mathrm{NTf}_{2}{ }^{-}\right]$with a low water content, but turns inhibited in the presence of an important water content. 


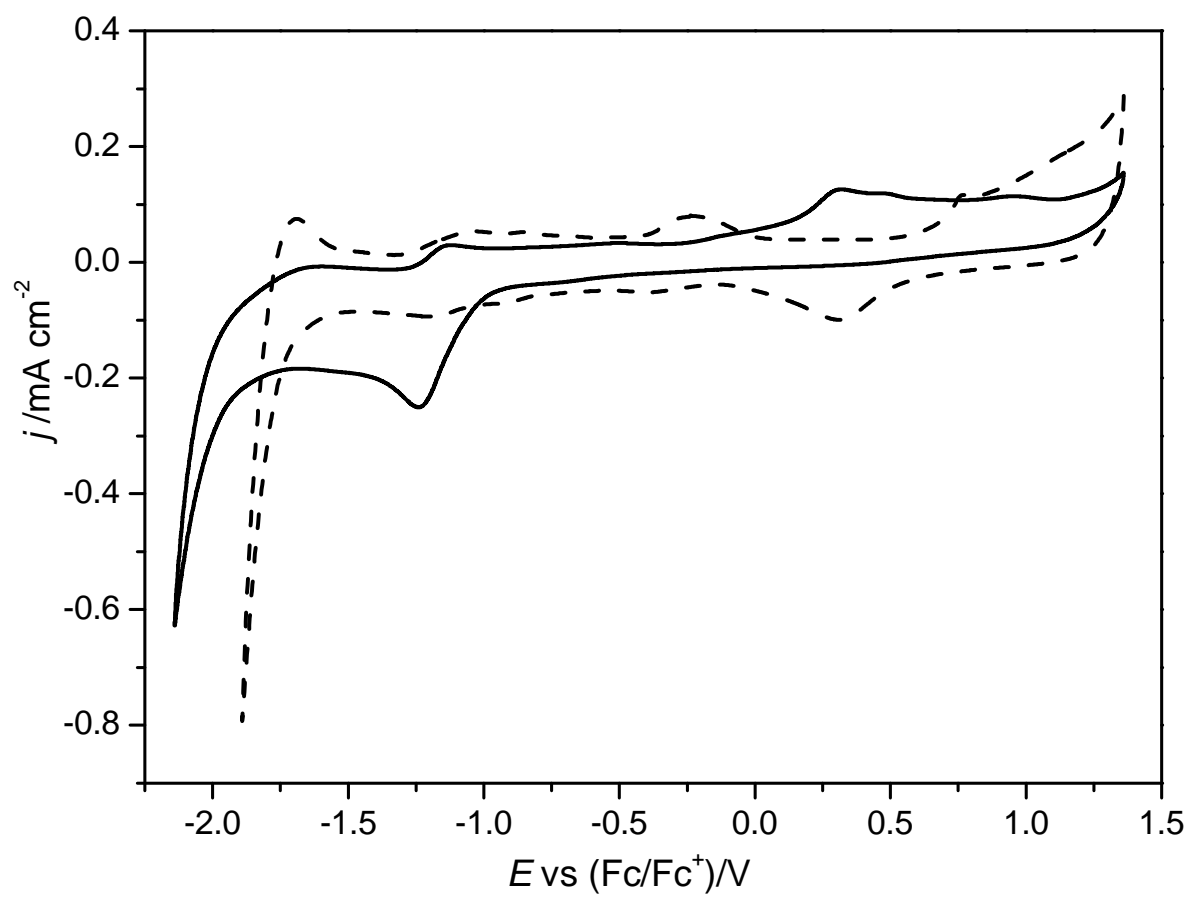

Figure 5. Voltammetric profile of Pt NPs in argon saturated $\left[\mathrm{C}_{4} \mathrm{mim}^{+}\right]\left[\mathrm{NTf}_{2}{ }^{-}\right]$containing 50 ppm $\mathrm{H}_{2} \mathrm{O}$ (black solid line) and 5680 ppm $\mathrm{H}_{2} \mathrm{O}$ (black dashed line) at $298 \mathrm{~K}$. Scan rate $50 \mathrm{mV} \mathrm{s}^{-1}$.

The temperature affects several properties of RTILs by increasing conductivity and ion mobility, but decreasing viscosity, among others $\left[{ }^{42}, 43,44\right]$. For this reason, we have studied this effect on $\left[\mathrm{C}_{4} \mathrm{mim}^{+}\right]\left[\mathrm{BF}_{4}{ }^{-}\right]$, since due to its high viscosity value (see Table 1 ) the temperature effect will be much more relevant in this case. This improvement in the diffusion of species in solution caused by increasing the temperature would be only relevant for the $\mathrm{OH}_{\text {ads }}$ diffusion, since the CO is already adsorbed on the Pt NPs surface, and would strongly influence the kinetics of electrochemical reactions. Thus, a higher temperature would allow a less positive potential for $\mathrm{CO}$ stripping, as is confirmed in Figure 6. Thus, the temperature effect is evaluated by keeping 
constant at $600 \mathrm{ppm}$ the water content in $\left[\mathrm{C}_{4} \mathrm{mim}^{+}\right]\left[\mathrm{BF}_{4}{ }^{-}\right]$for the stripping voltammetry of $\mathrm{CO}_{\mathrm{ads}}$ on Pt NPs at two different, but not too much, temperatures of 291 (red solid line) and $299 \mathrm{~K}$ (red dashed line). Despite the selected temperatures are only $8 \mathrm{~K}$ different, the CO stripping peak potential is shifted $180 \mathrm{mV}$ towards a less positive potential when the temperature is increased. Thus, this points out the tremendous effect of the temperature on the electrocatalytic properties of RTILs and the relevance of using a thermostatic electrochemical cell in this type of experiments. However, the charge involved in the $\mathrm{CO}_{\text {ads }}$ electrooxidation reaction remains almost constant at both temperatures (903.5 $\mu \mathrm{C} \mathrm{cm}^{-2}$ at $291 \mathrm{~K}$ and $894.5 \mu \mathrm{C} \mathrm{cm}{ }^{-2}$ at $\left.299 \mathrm{~K}\right)$, although the oxidation peak potential is clearly modified. This fact points out that, in this short temperature range, the $\mathrm{CO}$ coverage does not change significantly. These results clearly evidence that a fine control of the temperature is required to properly perform electrocatalytic studies in RTILs.

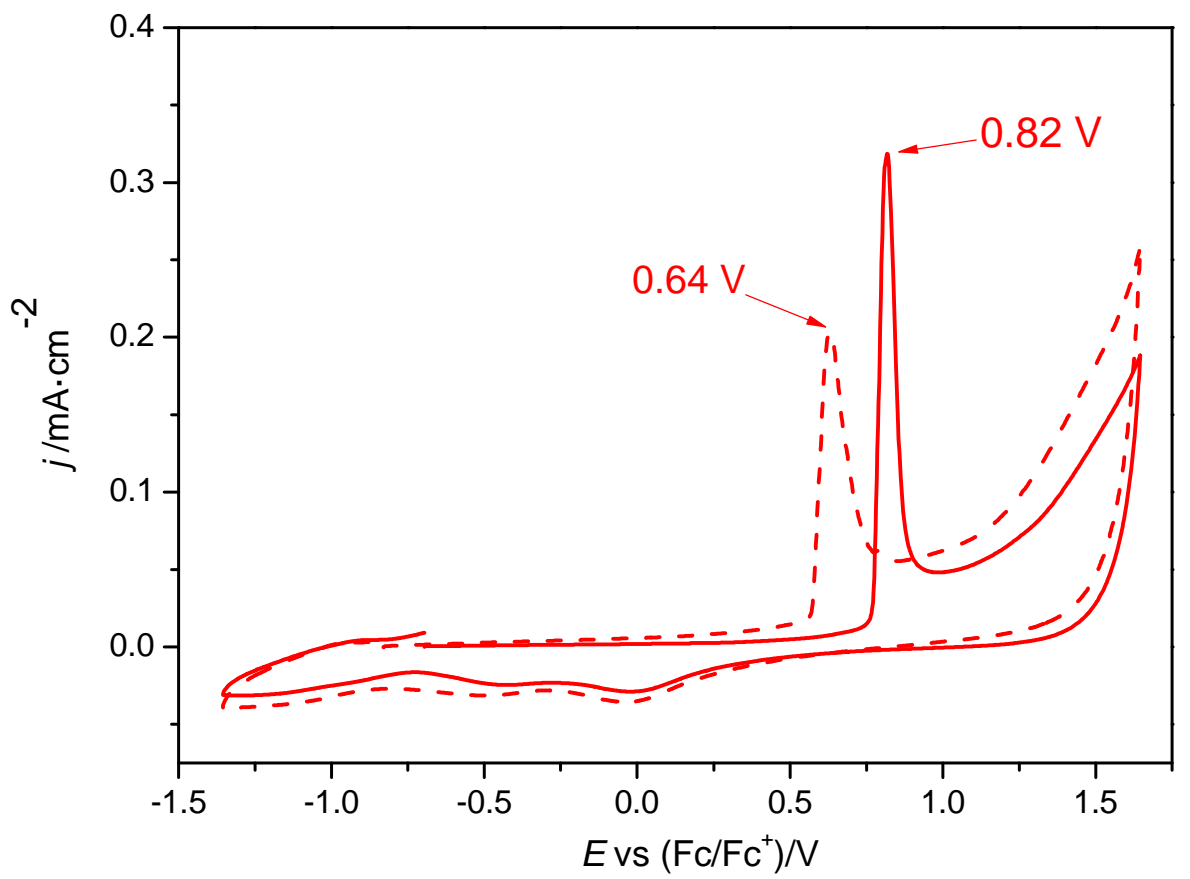


Figure 6. Stripping voltammetry of $\mathrm{CO}_{\text {ads }}$ on $\mathrm{Pt} \mathrm{NPs}$ in argon saturated $\left[\mathrm{C}_{4} \mathrm{mim}^{+}\right]\left[\mathrm{BF}_{4}{ }^{-}\right]$ containing $600 \mathrm{ppm} \mathrm{H}_{2} \mathrm{O}$. Scan rate $20 \mathrm{mV} \mathrm{s}^{-1}$. Two different temperatures are considered, $291 \mathrm{~K}$ (red solid line) and $299 \mathrm{~K}$ (red dashed line).

So far, it has been proved the importance that water content and temperature play in $\mathrm{CO}_{\mathrm{ads}}$ electrooxidation on $\mathrm{Pt}$ NPs in two different imidazolium-based ionic liquids, $\left[\mathrm{C}_{4} \mathrm{mim}^{+}\right]\left[\mathrm{NTf}_{2}^{-}\right]$and $\left[\mathrm{C}_{4} \mathrm{mim}^{+}\right]\left[\mathrm{BF}_{4}^{-}\right]$, which present a very different set of physical properties (see Table 1). However, the particular nature of ions forming the RTIL also represents a critical parameter, since the different specific adsorption of those ions controlled by their hydrophilic/hydrophobic character may also play an important role for the electrooxidation of $\mathrm{CO}_{\mathrm{ads}}$ on Pt surfaces [30]. Consequently, a distinct behavior as a function of the nature of the RTIL is expected even keeping basically constant temperature and water content. Figure 7A compares the $\mathrm{CO}_{\text {ads }}$ stripping voltammetry of Pt NPs in $\left[\mathrm{C}_{4} \mathrm{mim}^{+}\right]\left[\mathrm{NTf}_{2}\right]$ and $\left[\mathrm{C}_{4} \mathrm{mim}^{+}\right]\left[\mathrm{BF}_{4}^{-}\right]$. This comparison shows a clear peak potential difference between both RTILs as a consequence of their different physical properties, which are mainly determined by the nature of ions that form each RTIL. Figure 7B compares the distinctly background behaviour of the same Pt NPs in these two RTILs, which shows multiple signals whose nature still have to be fully understood. Nevertheless, the most interesting feature in figure 7 is not the specific potential at which the $\mathrm{CO}_{\mathrm{ads}}$ is oxidised and/or the presence of multiple and different contributions in the blank voltammograms in both RTILs, it is the different charge involved in the $\mathrm{CO}_{\text {ads }}$ electrooxidation depending on the RTIL used for the same amount and active surface of Pt NPs. Comparing both voltammograms shown in figure 7A, it is easy to realize that the charge involved in the $\mathrm{CO}_{\mathrm{ads}}$ electrooxidation in 
$\left[\mathrm{C}_{4} \mathrm{mim}^{+}\right]\left[\mathrm{BF}_{4}^{-}\right]\left(1150 \mu \mathrm{C} \mathrm{cm}{ }^{-2}\right)$ is higher than that obtained in $\left[\mathrm{C}_{4} \mathrm{mim}^{+}\right]\left[\mathrm{NTf}_{2}{ }^{-}\right]$ $\left(720 \mu \mathrm{C} \mathrm{cm}{ }^{-2}\right)$. A similar situation was observed by Hanc-Scherer et al. [26], since they reported a clear dependence in the charge associated with the $\mathrm{CO}_{\mathrm{ads}}$ electrooxidation process on $\mathrm{Pt}(h k l)$ with the nature of the imidazolium-based ionic liquid $\left(\left[\mathrm{C}_{2} \mathrm{~min}^{+}\right]\left[\mathrm{BF}_{4}{ }^{-}\right]\right.$and $\left.\left[\mathrm{C}_{2} \mathrm{~min}^{+}\right]\left[\mathrm{NTf}_{2}{ }^{-}\right]\right)$. In addition to this, these charge densities were remarkably higher than their value in aqueous solution (about $300 \mu \mathrm{C} \mathrm{cm}-2$ [27,29]), since values of about $1800-2100 \mu \mathrm{C} \mathrm{cm}^{-2}$ and $4500-5000$ $\mu \mathrm{C} \mathrm{cm}^{-2}$ were reported corresponding to $\left[\mathrm{C}_{2} \mathrm{~min}\right]\left[\mathrm{BF}_{4}\right]$ and $\left[\mathrm{C}_{2} \mathrm{~min}\right]\left[\mathrm{NTf}_{2}\right]$, respectively. An important part of this large difference between the charge density values reported here and those reported by Hanc-Scherer et al. [26] is due to the different method employed for subtracting the secondary competitive reactions involved, being more accurate the approach presented here and based on subtracting the following voltammogram after $\mathrm{CO}_{\text {ads }}$ stripping. 

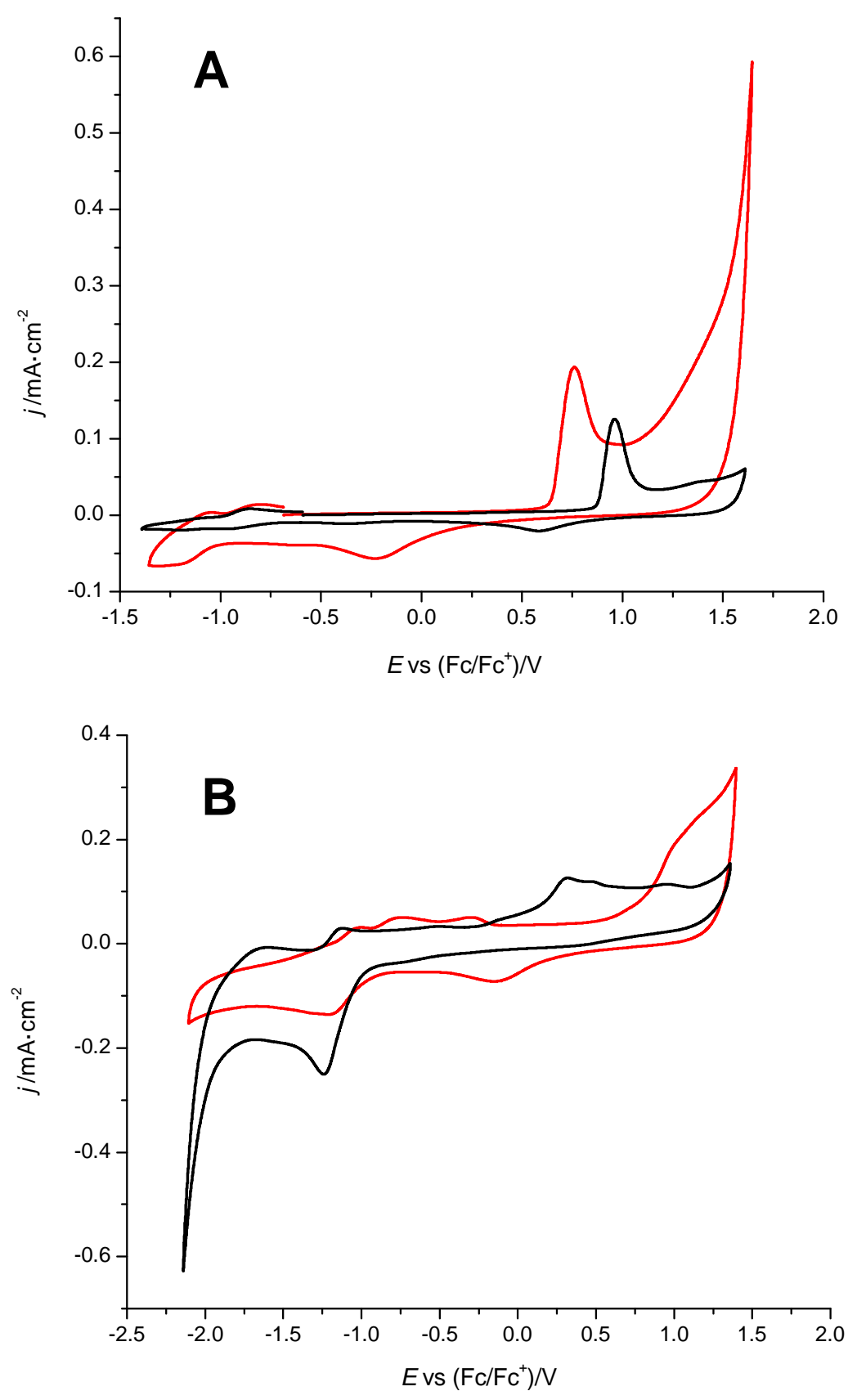

Figure 7. A) Stripping voltammetry of $\mathrm{CO}_{\mathrm{ads}}$ on Pt NPs in in argon saturated $\left[\mathrm{C}_{4} \mathrm{mim}^{+}\right]\left[\mathrm{BF}_{4}{ }^{-}\right]$containing $600 \mathrm{ppm} \mathrm{H}_{2} \mathrm{O}$ (red solid line) and $\left[\mathrm{C}_{4} \mathrm{mim}^{+}\right]\left[\mathrm{NTf}_{2}{ }^{-}\right]$containing 480 ppm $\mathrm{H}_{2} \mathrm{O}$ (black solid line). Temperature $298 \mathrm{~K}$. Scan rate $20 \mathrm{mV} \mathrm{s}$. B) Background voltammetric profile of clean Pt NPs in $\left[\mathrm{C}_{4} \mathrm{mim}^{+}\right]\left[\mathrm{BF}_{4}{ }^{-}\right]$containing $600 \mathrm{ppm}$ 
$\mathrm{H}_{2} \mathrm{O}$ (red solid line) and $\left[\mathrm{C}_{4} \mathrm{mim}^{+}\right]\left[\mathrm{NTf}_{2}^{-}\right]$containing 480 ppm $\mathrm{H}_{2} \mathrm{O}$ (black solid line). Temperature $298 \mathrm{~K}$. Scan rate $50 \mathrm{mV} \mathrm{s}^{-1}$.

A systematic study of the $\mathrm{Pt}$ loading employed in the $\mathrm{CO}_{\mathrm{ads}}$ electrooxidation reaction is performed in order to independently calculate the CO charge density for each RTIL studied here. Thus, the Pt loading is increased from 1 to $10 \mu \mathrm{L}$ of Pt NPs suspension, since within this range no diffusion limitations appear due to the Pt NPs agglomeration. For each Pt loading, the $\mathrm{CO}_{\text {ads }}$ stripping voltammetry is carried out and the $\mathrm{CO}$ stripping charge density measured. Then, these values are plotted versus the electroactive surface area of each sample (estimated from hydrogen UPD), as is shown in figure 8. A good linear regression is found for both RTILs, $\left[\mathrm{C}_{4} \mathrm{mim}^{+}\right]\left[\mathrm{BF}_{4}^{-}\right](8 \mathrm{~A})$ and $\left[\mathrm{C}_{4} \mathrm{mim}^{+}\right]\left[\mathrm{NTf}_{2}{ }^{-}\right](8 \mathrm{~B})$ suggesting that all surface is available for the electrochemical reaction within the studied Pt loading range. From the slope of those linear regressions, it is possible to estimate the charge of CO per unit of Pt surface area. Values of $1000 \mu \mathrm{C} \mathrm{cm}{ }^{-2}$ for $\left[\mathrm{C}_{4} \mathrm{mim}^{+}\right]\left[\mathrm{BF}_{4}{ }^{-}\right]$and $700 \mu \mathrm{C} \mathrm{cm}{ }^{-2}$ for $\left[\mathrm{C}_{4} \mathrm{mim}^{+}\right]\left[\mathrm{NTf}_{2}{ }^{-}\right]$are obtained. These charges densities are about 3 and 2 times higher, respectively, than the expected one from aqueous solution, but importantly much lower than those found in $\mathrm{Pt}(h k l)$ surfaces [26]. As was previously proposed by Hanc-Scherer et al [26], these higher CO stripping charge densities may be explained by a concomitant oxidation and/or adsorption of other species promoted by $\mathrm{CO}$ adsorption and oxidation on $\mathrm{Pt}$. In this regard, the difference between the two RTILs would be easily understandable taking into account their different nature. However, it is worth mention that we observe a higher $\mathrm{CO}$ stripping charge density when $\left[\mathrm{BF}_{4}{ }^{-}\right]$is the RTIL anion, which differs from previous findings reported by Hanc-Scherer 
et al. [26], since they reported higher $\mathrm{CO}$ stripping charge density for $\left[\mathrm{NTf}_{2}{ }^{-}\right]$. This apparent discrepancy may be due to different reasons including; i) the use of Pt single-crystal electrodes instead of Pt NPs, ii) the different nature of the cation employed $\left[\mathrm{C}_{2} \mathrm{mim}^{+}\right]$versus $\left[\mathrm{C}_{4} \mathrm{mim}^{+}\right]$and iii) the different method used for calculating the charge density involved in CO stripping avoiding contributions from secondary side reactions different than $\mathrm{CO}$ electrooxidation as it is reported here.

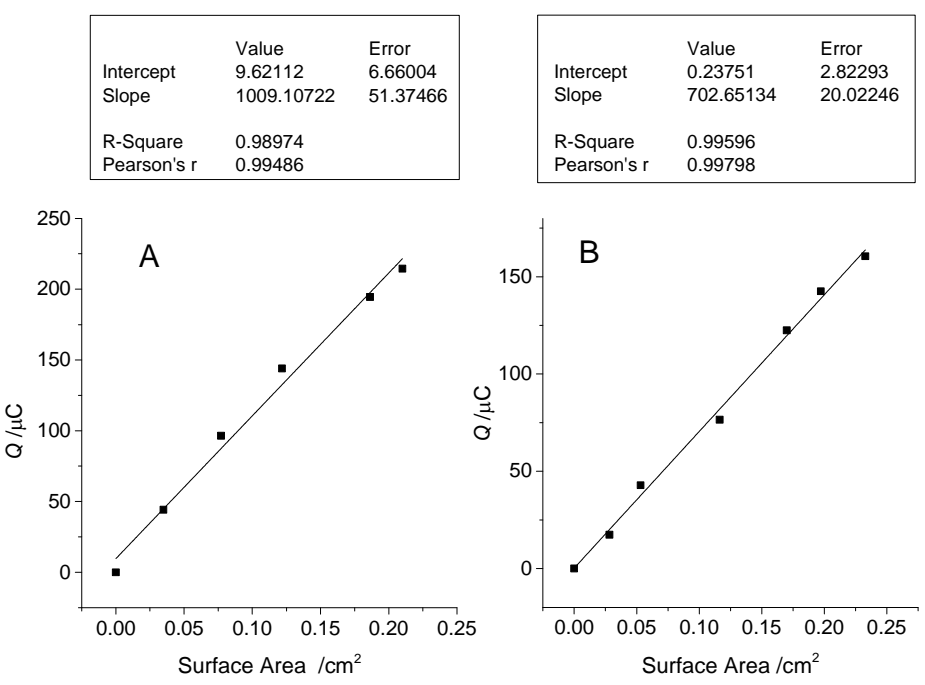

Figure 8. Correlation and linear regression of CO oxidative stripping peak charge versus Pt NPs surface area in argon saturated $(A)\left[\mathrm{C}_{4} \mathrm{mim}^{+}\right]\left[\mathrm{BF}_{4}{ }^{-}\right]$containing $600 \mathrm{ppm}$ $\mathrm{H}_{2} \mathrm{O}$ and $(\mathrm{B})\left[\mathrm{C}_{4} \mathrm{mim}^{+}\right]\left[\mathrm{NTf}_{2}{ }^{-}\right]$containing $480 \mathrm{ppm} \mathrm{H}_{2} \mathrm{O}$. Temperature $298 \mathrm{~K}$.

The electrocatalyst degradation under working conditions in aqueous media represents a major concern nowadays $\left[{ }^{45}\right]$. For this reason, we consider necessary to study the stability of Pt NPs in the imidazolium-based ionic liquids, since not much information has been reported regarding the degradation of catalysts in RTILs. One of the main advantages of working in RTILs is their wide 
potential windows. For instance, in the experiments presented here the difference between reduction and oxidation limits are up to $3 \mathrm{~V}$ in $\left[\mathrm{C}_{4} \mathrm{mim}^{+}\right]\left[\mathrm{BF}_{4}{ }^{-}\right]$ and $\left[\mathrm{C}_{4} \mathrm{mim}^{+}\right]\left[\mathrm{NTf}_{2}{ }^{-}\right]$, far away from the $(0.8-0.9) \mathrm{V}$ normally reached in aqueous media. Thus, it is a relevant question knowing the effect of those extreme applied potential values in the stability of Pt NPs. For this purpose, we propose the comparison of the characteristic voltammograms of Pt NPs in aqueous sulfuric solution, before and after the interaction between Pt NPs and the corresponding RTIL, as a suitable method to evaluate the Pt NPs stability (or degradation) in RTILs media. Figure 9 shows three different voltammograms of Pt NPs in $0.5 \mathrm{M} \mathrm{H}_{2} \mathrm{SO}_{4}$ aqueous solution before and after being exposed to $\left[\mathrm{C}_{4} \mathrm{mim}^{+}\right]\left[\mathrm{BF}_{4}^{-}\right]$(figure $9 \mathrm{~A}$ ) and $\left[\mathrm{C}_{4} \mathrm{mim}^{+}\right]\left[\mathrm{NTf}_{2}{ }^{-}\right]$(figure 9B), respectively. In both cases, the hydrogen adsorption features at 0.12 and $0.27 \mathrm{~V}$ present in the initial Pt NPs (blue solid plot in figures 9A and 9B), are completely masked due to the $\left[\mathrm{C}_{4} \mathrm{mim}^{+}\right]$adsorption when the voltammogram is performed after $\mathrm{Pt}$ NPS immersion and polarization in the RTILs. This polarization comprises a wide potential range (from $-2 \vee$ to $1.75 \vee$ vs $F c / F c^{+}$) and at least 2 hours of cycling (red solid plot in figure 9A and black solid plot in figure 9B). Electroactive surface area of Pt NPs evaluated by hydrogen UPD in $0.5 \mathrm{M} \mathrm{H}_{2} \mathrm{SO}_{4}$ aqueous solution before and after immersion in RTILs and after additional $\mathrm{CO}_{\text {ads }}$ stripping voltammetry are summarized in table 2 . The remaining available surface on $\mathrm{Pt}$ NPs after $\left[\mathrm{C}_{4} \mathrm{mim}^{+}\right]$adsorption is almost constant in both cases and represents $78 \%$ of the initial surface in the $\left[\mathrm{C}_{4} \mathrm{mim}^{+}\right]\left[\mathrm{BF}_{4}{ }^{-}\right]$case and $74 \%$ in the $\left[\mathrm{C}_{4} \mathrm{mim}^{+}\right]\left[\mathrm{NTf}_{2}{ }^{-}\right]$case. However, this apparent loss of available area on the $\mathrm{Pt}$ NPs does not necessary mean degradation, since it may be also justify by a blocking layer of $\left[\mathrm{C}_{4} \mathrm{mim}^{+}\right]$cations adsorbed on the surface. Thus, a $\mathrm{CO}_{\mathrm{ads}}$ 
stripping voltammetry in aqueous solution is performed on those Pt NPs in order to displace by $\mathrm{CO}$ the ions adsorbed on the Pt NPs and clarify the source of Pt surface area loss. The resulting voltammograms after performing the $\mathrm{CO}$ displacement experiment (blue dashed line in figure 9A and 9B) exhibit a 90\% of the initial surface. Thus, only a 10\% of the initial Pt NPs surface area may not be recovered after immersion and polarization in those RTILs. This actual loss of surface area in Pt NPs can be considered as an electrocatalyst degradation and may be probably due to the slight sintering of Pt NPs due to the aggressive potential conditions employed. Thus, we have demonstrated that it is possible to work with Pt NPs in these novel reaction media by cycling them within a large potential range, but remaining mainly stable, since the electrocatalyst surface remains very close to the one initially present in the material. 

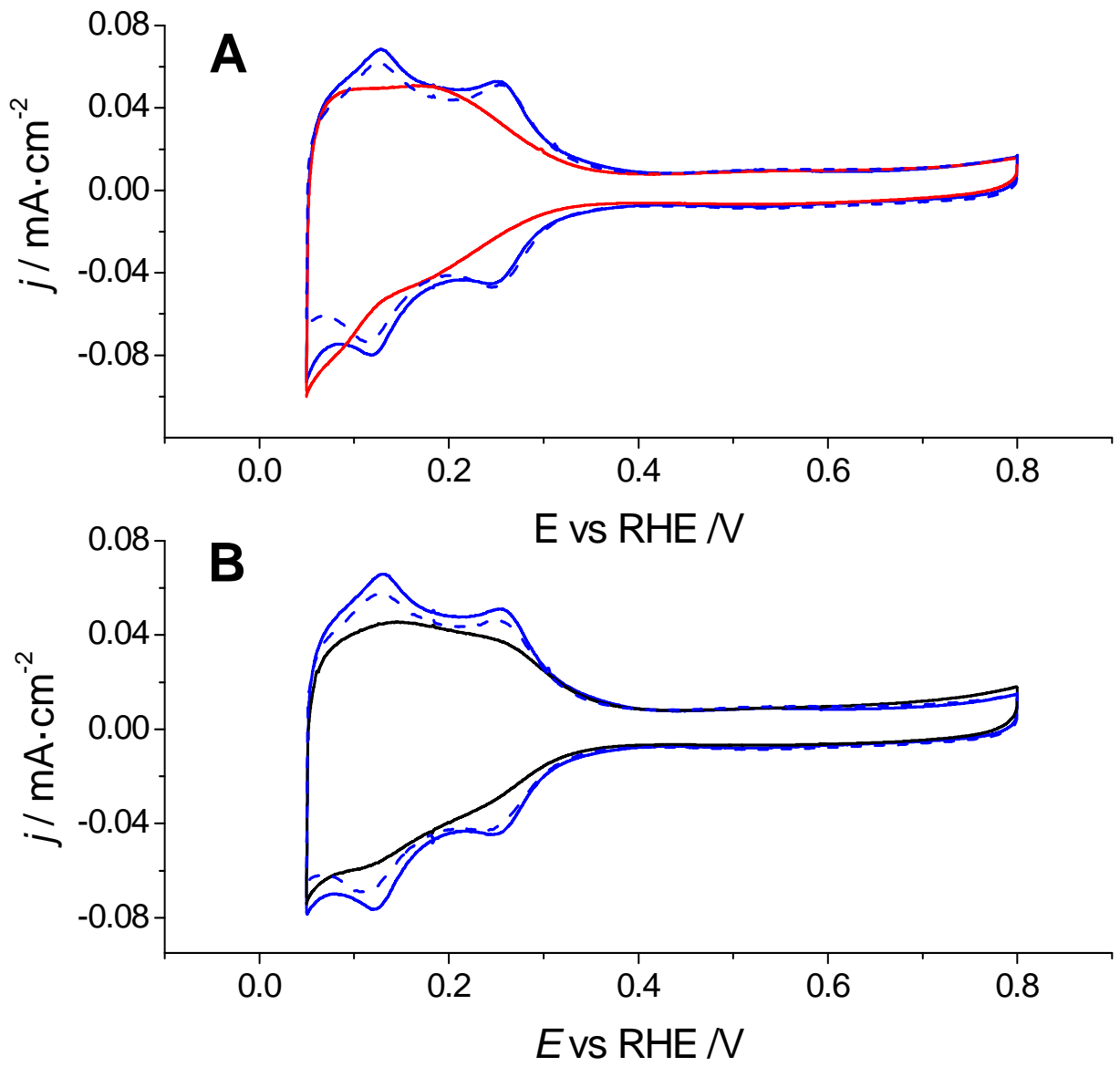

Figure 9 Voltammetric profile of Pt NPs in $0.5 \mathrm{M} \mathrm{H}_{2} \mathrm{SO}_{4}$ aqueous deaerated solution at $50 \mathrm{mV} \mathrm{s}^{-1}$. A) $\left[\mathrm{C}_{4} \mathrm{mim}^{+}\right]\left[\mathrm{BF}_{4}^{-}\right]$containing $600 \mathrm{ppm} \mathrm{H}_{2} \mathrm{O}$ and (B) $\left[\mathrm{C}_{4} \mathrm{mim}^{+}\right]\left[\mathrm{NTf}_{2}{ }^{-}\right]$ containing 480 ppm $\mathrm{H}_{2} \mathrm{O}$. Temperature $298 \mathrm{~K}$. Blue solid plot corresponds to the initial Pt NPs, red solid plot corresponds to the Pt NPs after immersion and polarization in $\left[\mathrm{C}_{4} \mathrm{mim}^{+}\right]\left[\mathrm{BF}_{4}^{-}\right]$, black solid plot corresponds to the Pt NPs after immersion and polarization in $\left[\mathrm{C}_{4} \mathrm{mim}^{+}\right]\left[\mathrm{NTf}_{2}{ }^{-}\right]$and blue dashed plots corresponds to the final Pt NPs, after $\mathrm{CO}$ displacement cleaning treatment.

Table 2. Evaluation of the electroactive surface area of Pt NPs measured by hydrogen UPD in $0.5 \mathrm{M} \mathrm{H}_{2} \mathrm{SO}_{4}$ aqueous solution, before and after immersion in RTILs and after $\mathrm{CO}_{\text {ads }}$ stripping voltammetry. 


\begin{tabular}{|l|c|c|c|c|c|}
\hline & $\begin{array}{c}\text { Before } \\
\mathrm{RTIL} \\
\left(\mathrm{cm}^{2} \mathrm{Pt}\right)\end{array}$ & $\begin{array}{c}\text { After } \\
\mathrm{RTIL} \\
\left(\mathrm{cm}{ }^{2} \mathrm{Pt}\right)\end{array}$ & $\begin{array}{c}\text { Surface } \\
\text { recovered } \\
(\%)\end{array}$ & $\begin{array}{c}\text { After CO } \\
\text { stripping } \\
\left.(\mathrm{cm})^{2} \mathrm{Pt}\right)\end{array}$ & $\begin{array}{c}\text { Surface } \\
\text { recovered } \\
(\%)\end{array}$ \\
\hline$\left[\mathrm{C}_{4} \mathrm{mim}^{+}\right]\left[\mathrm{BF}_{4}{ }^{-}\right]$ & 0.237 & 0.186 & 78 & 0.215 & 90 \\
\hline$\left[\mathrm{C}_{4} \mathrm{mim}^{+}\right]\left[\mathrm{NTf}_{2}{ }^{-}\right]$ & 0.197 & 0.146 & 74 & 0.172 & 90 \\
\hline
\end{tabular}

\section{Conclusions}

The electrocatalytic behavior of synthesized quasi-spherical Pt NPs in two different imidazolium-based RTILs has been studied taking as a model the $\mathrm{CO}_{\text {ads }}$ electrooxidation reaction in $\left[\mathrm{C}_{4} \mathrm{mim}^{+}\right]\left[\mathrm{NTf}_{2}{ }^{-}\right]$and $\left[\mathrm{C}_{4} \mathrm{mim}^{+}\right]\left[\mathrm{BF}_{4}^{-}\right]$. The important effects played by water content, temperature and nature of RTIL have been studied. The $\mathrm{CO}_{a d s}$ oxidation peak potential has shown great sensitivity depending on the RTIL water content and temperature, which have pointed out the importance of performing Karl Fisher titrations to the RTILs and using a thermostatic electrochemical cell. However, in all cases the charge density value associated to the $\mathrm{CO}$ oxidation peak remains mainly constant, only the nature of the ions forming the RTIL provokes an important variation in that charge density for $\mathrm{CO}$ electrooxidation. A new method based on subtracting the following voltammogram after $\mathrm{CO}_{\text {ads }}$ stripping is proposed for suitable evaluation of the charge density strictly corresponding to the CO stripping peak, without any contribution from secondary competitive reactions. Finally, we evaluated the Pt NPs electrocatalyst degradation in RTILs, considered as loss of electrochemically active area, by comparing the characteristic voltammograms of Pt NPs in aqueous sulfuric solution, before and after the interaction between the Pt NPs and the corresponding RTIL under study. Only a $10 \%$ loss of the initial electroactive area is reported after performing a CO stripping voltammetry in Pt NPs immersed and polarized in 
RTILs. We consider Pt NPs sintering during polarization in $\left[\mathrm{C}_{4} \mathrm{mim}^{+}\right]\left[\mathrm{NTf}_{2}{ }^{-}\right]$and $\left[\mathrm{C}_{4} \mathrm{mim}^{+}\right]\left[\mathrm{BF}_{4}\right]$ as the main source for this $10 \%$ of degradation.

\section{Acknowledgement}

This work has been financially supported by the MICINN (Spain) (project CTQ2013-48280-C3-3-R). 


\section{References}

\footnotetext{
${ }^{1}$ Hapiot P, Lagrost C (2008) Electrochemical Reactivity in Room-Temperature Ionic Liquids. Chem Rev 108:2238-2264

${ }^{2}$ Endres F, El Abedin SZ (2006) Air and water stable ionic liquids in physical chemistry. Phys Chem Chem Phys 8:2101-2116

${ }^{3}$ Pandey S (2005) Analytical applications of room-temperature ionic liquids: A review of recent efforts. Anal Chim Acta 556:38-45

${ }^{4}$ Erdem A, Muti M, Mese F, Eksin E (2014) Chitosan-ionic liquid modified single-use sensor for electrochemical monitoring of sequence-selective DNA hybridation. Colloids Surf, B 114:261-268
}

${ }^{5}$ Harun M, Sabri F, Muen I, Ali M, Azlan M, Bahadori L, Low CTJ (2014) Prospects of applying ionic liquids and deep eutectic solvents for renewable energy storage by means of redox flow batteries. Renew Sust Energ Rev 30:254-270

${ }^{6}$ De Souza RF, Padilha JC, Gonçalves RS, Dupont J (2003) Room temperature dialkylimidazolium ionic liquid-based fuel cells. Electrochem Commun 5:728-731

${ }^{7}$ Galinski M, Lewandowski A, Stepniak I (2006) Ionic liquids as electrolytes. Electrochim Acta 51:55675580

${ }^{8}$ O’Mahony AM, Silvester DS, Aldous L, Hardacre C, Compton RG (2008) Effect of Water on the Electrochemical Window and Potential Limits of Room-Temperature Ionic Liquids. J Chem Eng Data 53:2884-2891

${ }^{9}$ Darling HE (1964) Conductivity of sulfuric acid solutions. J Chem Eng Data 9:421-426

${ }^{10}$ Rhodes FH, Barbour CB (1923) The viscosities of mixtures of sulfuric acid and water. Ind Eng Chem 15:850-852

${ }^{11}$ Wen Z, Liu J, Li J (2008) Core/Shell Pt/C Nanoparticles Embedded in Mesoporous Carbon as a Methanol-Tolerant Cathode Catalyst in Direct Methanol Fuel Cells Adv Mater 20:743-747

${ }^{12}$ Song C (2002) Fuel processing for low-temeprature and high-temperature fuel cells Challengues, and opportunities for sustainable development in the $21^{\text {st }}$ century. Catal Today 77:17-49

${ }^{13}$ Liu R, Duay J, Lee SB (2011) Heterogeneous nanostructured electrode materials for electrochemical energy storage. Chem Commun 47:1384-1404

${ }^{14}$ Rigsby MA, Zhou WP, Lewera A, Duong HT, Bagus PS, Jaegermann W, Hunger R, Wieckowski A (2008) Experiment and Theory of Fuel Cell Catalysis: Methanol and Formic Acid Decomposition on Nanoparticle Pt/Ru. J Phys Chem C 112:15595-15601

${ }^{15}$ Neyerlin KC, Srivastava R, Yu C, Strasser P (2009) Electrochemical activity and stability of dealloyed $\mathrm{Pt}-\mathrm{Cu}$ and Pt-Cu-Co electrocatalysts for the oxygen reduction reaction (ORR). J Power Sources 186:261267

${ }^{16}$ Solla-Gullón J, Montiel V, Aldaz A, Clavilier J (2000) Electrochemical characterization of platinum nanoparticles prepares by microemulsion: how to clean them without loss of crystalline surface structure. J Electroanal Chem 491:69-77

17 Sánchez-Sánchez CM, Solla-Gullón J, Vidal-Iglesias FJ, Aldaz A, Montiel V, Herrero E (2010) Imaging Structure Sensitive Catalysis on Different Shape-Controlled Platinum Nanoparticles. J Am Chem Soc 132:5622-5624 
${ }^{18}$ Vidal-Iglesias FJ, Solla-Gullón J, Montiel V, Feliu JM, Aldaz A (2007) Screening of electrocatalysts for direct ammonia fuel cell: Ammonia oxidation on PtMe (Me: Ir, Rh, Pd, Ru) and preferentially oriented Pt(100) nanoparticles. J Power Sources 171:448-456

${ }^{19}$ Lou J, Wang L, Mott D, Njoki PN, Lin Y, He T, Xu A, Wanjana BN, Lim IS, Zhong CJ (2008) Core/shell Nanoparticles as Electrocatalysts for Fuel Cell Reactions. Adv Mater 20:4342-4347

${ }^{20}$ Wang X, You Z, Cheng Y, Sha H, Li G, Zhu H, Sun W (2015) Application of nanosized gold and graphene modified carbon ionic liquid electrode for the sensitive electrochemical determination of folic acid. J Mol Liq 204:112-117

${ }^{21}$ Wang D, Dou W, Zhao G, Chen Y (2014) Immunosensor based on electrodeposition of goldnanoparticles and ionic liquid composite for detection of Salmonella pullorum. J Microbiol Meth 106:110-118

${ }^{22}$ Zhang D, Chang WC, Okajima T, Ohsaka T (2011) Electrodeposition of Platinum Nanoparticles in a Room-Temperature Ionic Liquid. Langmuir 27:14662-14668

${ }^{23}$ Zhang G, Zhou H, An C, Liu D, Huang Z, Kuang Y (2012) Bimetallic palladium-gold nanoparticles synthesized in ionic liquid microemulsion. Colloid Polym Sci 290:1435-1441

${ }^{24}$ Wang X, Cheng Y, You Z, Sha H, Gong S, Liu J, Sun W (2015) Sensitive electrochemical determination of oxalic acid in spinach samples by a graphene-modified carbon ionic liquid electrode. Ionics 21:877-884

${ }^{25}$ Ghilane J, Lacroix J-C (2013) Formation of a Bifunctional Redox System Using Electrochemical Reduction of Platinum in Ferrocene Based Ionic Liquid and Its Reactivity with Aryldiazonium. J Am Chem Soc 135:4722-4728

${ }^{26}$ Hanc-Scherer FA, Sánchez-Sánchez CM, Ilea P, Herrero E (2013) Surface-Sensitive Electrooxidation of Carbon Monoxide in Room Temperature Ionic Liquids. ACS Catal 3:2935-2938

${ }^{27}$ Herrero E, Alvarez B, Feliu JM, Blais S, Radovic-Hrapovic Z, Jerkiewicz G (2004) Temperature dependence of the $\mathrm{CO}_{\mathrm{ads}}$ oxidation process on $\mathrm{Pt}(111)$, $\mathrm{Pt}(100)$ and $\mathrm{Pt}(110)$ electrodes. J Electroanal Chem 567:139-149

${ }^{28}$ Ejigu A, Johnson L, Licence P, Walsh DA (2012) Electrocatalytic oxidation of metanol and carbón monoxide at platinum in protic ionic liquids. Electrochem Commun 23:122-124

${ }^{29}$ Herrero E, Feliu JM, Blais S, Radovec-Hrapovic Z, Jerkiewicz G (2000) Temperature Dependance of CO Chemisorption and Its Oxidative Desorption on the Pt (111) Electrode. Langmuir 16:4779-4783

${ }^{30}$ Ejigu A, Walsh DA (2014) The role of Adsorbed Ions during Electrocatalysis in Ionic Liquids. J Phys Chem C 118:7414-7422

${ }^{31}$ Yang YY, Zhang LN, Osawa M, Cai WB (2013) Surface-Enhanced Infrared Spectroscopic Study of a CO-Covered Pt Electrode in Room-Temperature Ionic Liquid. J Phys Chem Lett 4:1582-1586

${ }^{32}$ Baldelli S (2008) Surface Structure at the Ionic Liquid-Electrified Metal Interface. Accounts Chem Res 41:421-431

${ }^{33}$ Aliaga C, Santos CS, Baldelli S (2007) Surface chemistry of room-temperature ionic liquids. Phys Chem Chem Phys 9:3683-3700

${ }^{34}$ Baldelli S (2005) Probing Electric Field at the Ionic Liquid-Electrode Interface Using Sum Frequency Generation Spectroscopy and Electrochemistry. J Phys Chem B 109:13049-13051

${ }^{35}$ Lewandowski A, Waligora L, Galinski M (2009) Ferrocene as Reference Redox Couple for Aprotic Ionic Liquids. Electroanal 21:2221-2227 
36 Trasatti S, Petrii OA (1991) Real Surface-Area Measurements in Electrochemistry. Pure Appl Chem 63:711-734

${ }^{37}$ Solla-Gullón J, Rodríguez P, Herrero E, Aldaz A, Feliu JM (2008) Surface characterization of Pt electrodes. Phys Chem Chem Phys 10:1359-1373

${ }^{38}$ Solla-Gullón J, Vidal-Iglesias F.J., López-Cudero A, Garnier E, Feliu JM, Aldaz A (2008) Shapedependent electrocatalysis: methanol and formic acid electrooxidation on preferentially oriented $\mathrm{Pt}$ nanoparticles. Phys Chem Chem Phys 10:3689-3698

${ }^{39}$ Widegren JA, Saurer EM, Marsh KN, Magee JW (2005) Electrolytic conductivity of four imidazoliumbased room-temperature ionic liquids and the effect of a water impurity. J Chem Thermodynamics 37:569-575

${ }^{40}$ Ries LAS, do Amaral FA, Matos K, Martini EMA, de Souza MO, de Souza RF (2008) Evidence of change in the molecular organization of 1-n-butyl-2-methylimidazolium tetrafluoroborate ionic liquid solutions with the addition of water. Polyhedron 27:3287-3293

${ }^{41}$ Di Noto V, Negro E (2009) Pt-Fe and Pt-Ni Carbon Nitride-Based 'Core-Shell’ ORR Electrocatalysts for Polymer Electrolyte Membrane Fuel Cells. Fuel Cells 10:234-244

${ }^{42}$ Okoturo OO, VanderNoot TJ (2004) Temperature dependance of viscosity for room temperatura ionic liquids. J Electroanal Chem 568:167-181

${ }^{43}$ Nishida T, Tashiro Y, Yamamoto M (2002) Physical and electrochemical properties of 1-alkyl-3methylimidazolium tetrafluoroborate for electrolyte. J Fluorine Chem 120:135-141

${ }^{44}$ Zhang J, Bond AM (2005) Practical considerations associated with voltammetric studies in room temperatura ionic liquids. Analyst 130:1132-1147

${ }^{45}$ Chang SH, Connell JG, Danilovic N, Subbaraman R, Chang K-C, Stamenkovic VR, Markovic NM (2014) Activity-stability relationship in the surface electrochemistry of the oxygen evolution reaction. Faraday Discuss 176:125-133 